\title{
PROYEKSI KESESUAIAN AGROKLIMAT TANAMAN PADI BERDASARKAN SKENARIO REPRESENTATIVE CONCENTRATION PATHWAYS (RCP)4.5 DAN RCP8.5 DI PROVINSI JAWA TIMUR
}

\author{
Femmy Marsitha B $^{1^{*}}$, Suwandi ${ }^{1}$ \\ ${ }^{1}$ Sekolah Tinggi Meteorologi Klimatologi dan Geofisika, Jakarta \\ *Email :femmymarsitha@.email
}

\begin{abstract}
ABSTRAK
Untuk menyediakan dukungan sains melawan dampak dari perubahan iklim, analisis kesesuaian iklim hingga masa depan perlu dilakukan agar perencanaan penanaman padi di Jawa Timur terencana dengan baik. Penelitian ini bertujuan untuk mengetahui perubahan kesesuaian agroklimat tanaman padi menggunakan skenario RCP4.5 dan RCP8.5 dengan model CSIRO resolusi $25 \mathrm{~km}$ dengan periode sekarang (baseline) tahun 1996-2005 dan periode proyeksi, yaitu Future 1 (2021-2030) dan Future 2 (2031-2040). Data observasi yang digunakan adalah curah hujan bulanan untuk menentukan tipe iklim Oldeman, suhu udara rata-rata bulanan, dan ketinggian tempat pada setiap titik pengamatan yang mewakili ZOM. Hasil penelitian menunjukkan bahwa dibawah skenario RCP4.5 pada Future 1, faktor iklim tidak menjadi hambatan bagi petani karena didominasi oleh S1 sedangkan pada Future 2 dan dibawah skenario RCP8.5 pada kedua periode, faktor iklim menjadi halangan bagi petani sehingga memerlukan tambahan masukan baik irigasi maupun teknologi pada kedua periode di masa depan karena terdapat penambahan kondisi S3 dan $N$.
\end{abstract}

Kata kunci : Kesesuaian agroklimat, RCP4.5, RCP8.5, perubahan iklim, tanaman padi

\begin{abstract}
To provide scientific support against effect of climate change, agroclimate suitability analysis up to the future need to be done in order to plan rice plantation. This research aimed to determine changes in paddy rice agroclimate suitability using RCP4.5 and RCP8.5 scenarios with $25 \mathrm{~km}$ resolution CSIRO climate model. Present period as a baseline is 1996-2005 and near projection period, Future 1 (2021-2030) and Future 2 (2031-2040) are used. Observation data consist of monthly rainfall to determine Oldeman climate type, monthly mean temperature, and elevation on all representative observation stations of ZOM. The result showed that under RCP4.5 scenario in Future 1, climate factors are not an obstacle for farmer while in Future 2 and under RCP8.5 scenario on both period, climate factors are be an obstacle in East Java so need more inputs such as irrigation and another technology because of $S 3$ and $N$ additional conditions.
\end{abstract}

Keywords : Agroclimate suitability, RCP4.5, RCP8.5, climate change, paddy rice plants.

\section{PENDAHULUAN}

Berdasarkan laporan IPCC tahun 2007, perubahan iklim diprediksi terjadi seiring dengan peningkatan konsentrasi Gas Rumah Kaca (GRK) yang mengakibatkan meningkatnya temperatur rata-rata permukaan bumi secara global dalam lima puluh tahun terakhir. Salah satu dampaknya adalah perubahan pola iklim yang menyebabkan tidak menentunya kondisi iklim seperti perubahan distribusi curah hujan baik secara spasial maupun temporal serta memicu peningkatan peluang kejadian cuaca dan iklim ekstrim (Trenberth dkk., 2003). Hal ini 
diklaim memberi dampak negatif terhadap sumber air dan pertanian di Asia dan di beberapa negara berkembang. Meningkatnya frekuensi kejadian kekeringan dan banjir akan menurunkan produktivitas tanaman pangan dan dapat menyebabkan kegagalan panen.

Indonesia memiliki tiga provinsi sebagai pusat penghasil padi terbesar, yaitu Jawa Timur yang menduduki posisi pertama dengan jumlah produksi sebesar 13.15 juta ton, Jawa Barat dengan jumlah produksi 11.37 juta ton dan Jawa Tengah 11.30 juta ton (BPS, 2015). Dalam bidang pertanian, menemukan lokasi yang optimal untuk suatu tanaman dapat meningkatkan keberhasilan panen dan mengurangi dampak buruk yang disebabkan oleh lingkungan. Suatu tanaman dalam waktu singkat akan menjadi tidak produktif jika tanaman tersebut dipaksa tumbuh di lokasi yang tidak sesuai, kecuali jika dilakukan perbaikan misalnya masukan teknologi (Kandari dkk., 2013).

Untuk mempertahankan dan mendukung ketahanan pangan nasional, maka perlu antisipasi melalui adaptasi dan mitigasi dampak perubahan iklim terhadap pertanian. Sehingga, penulis melakukan kajian mengenai dampak perubahan iklim terhadap perubahan kesesuaian agroklimat tanaman padi di Provinsi Jawa Timur.

Gambaran alternatif kondisi iklim di masa depan diketahui menggunakan skenario iklim, salah satunya adalah Representative Concentration Pathways (RCP). Skenario RCP merupakan skenario yang didasarkan pada riset dengan empat pemodelan iklim yang disetarakan dengan konsentrasi gas karbon yaitu RCP2.6, RCP4.5, RCP6.0 dan RCP8.5 (IPCC AR5, 2013). Dalam penelitan ini, penulis mengkaji proyeksi iklim menggunakan skenario RCP4.5 dan RCP8.5 dengan model CSIRO luaran General Circulation Model (GCM) dengan resolusi 25 x $25 \mathrm{~km}$. Skenario RCP4.5 memiliki keunggulan yang sudah sesuai dengan keadaan sekarang dimana ada kebijakan untuk membatasi emisi GRK melalui protokol Kyoto. Sedangkan skenario RCP8.5 sebagai skenario pembanding dengan melihat kemungkinan terburuk kondisi iklim di masa depan apabila tidak ada kebijakan untuk membatasi emisi GRK.

\section{DATA DAN METODE}

Data observasi curah hujan bulanan di 60 titik pengamatan yang mewakili ZOM dan suhu udara rata-rata bulanan pada beberapa stasiun referensi digunakan dalam penelitian ini dengan periode tahun 1996-2005. Selanjutnya, untuk menduga suhu di pos hujan, digunakan formuala Braak (1928) berdasarkan ketinggian tempat berikut:

$T h=T h_{0}-(0,6 \times h \times 0.01)$

dengan Th adalah suhu udara pada pos hujan, $\mathrm{Th}_{0}$ adalah suhu udara stasiun referensi, $\mathrm{h}$ adalah selisih ketinggian pos hujan dengan stasiun referensi (mdpl). Data model CSIRO yang telah ditingkatkan resolusinya menjadi $25 \mathrm{~km}$ untuk menggambarkan kondisi variable curah hujan dan suhu pada periode baseline (1996-2005) dan kondisi masa depan dengan scenario RCP4.5 dan RCP8.5, yaitu Future 1 (2021-2030) dan Future 2 (2031-2040).

Curah hujan bulanan dikoreksi dengan formula berikut (Weiland dkk., 2010):

$C H_{M O D E L} K O R=C H_{M O D} \times \frac{\overline{C H_{O B S}}}{\overline{C H_{M O D}}} \ldots$

dengan $\mathrm{CH}$ MODEL_KOR adalah curah hujan bulanan model setelah dikoreksi, $\mathrm{CH}{ }_{M O D}$ adalah curah hujan bulanan model sebelum dikoreksi, $\overline{\mathrm{CH}_{O B S}}$ adalah rata-rata curah hujan bulanan periode baseline data pengamatan, dan $\overline{C H_{M O D}}$ adalah rata-rata curah hujan bulanan periode baseline data model. Sedangkan untuk suhu udara dikoreksi menggunakan formula berikut (Weiland dkk., 2010):

$T_{\text {MODEL } \_K O R}=T_{M O D}+\left(\overline{T_{O B S}}-\overline{T_{M O D}}\right)$

dengan $T_{\text {MODEL_KOR }}$ adalah temperatur bulanan model setelah dikoreksi, $T$ MOD adalah temperatur bulanan model sebelum dikoreksi, $\overline{T_{O B S}}$ adalah rata-rata temperatur bulanan periode baseline data pengamatan, dan $\overline{T_{M O D}}$ adalah rata-rata temperatur bulanan periode baseline data model.

Menurut FAO (1976) dalam kerangka kerja untuk evaluasi lahan, kesesuaian lahan adalah tingkat kecocokan suatu bidang lahan untuk suatu penggunaan tanaman tertentu. Sedangkan agroklimatologi merupakan ilmu 
yang mempelajari tentang pengaruh unsurunsur iklim dengan proses kehidupan tanaman (Meteorology Glossary). Sehingga, kesesuaian agroklimat adalah tingkat kecocokan unsur-unsur iklim untuk suatu kehidupan tanaman pada suatu bidang lahan. Klasifikasi kesesuaian lahan adalah penilaian dan pengelompokan atau proses penilaian dan pengelompokan lahan dalam arti kesesuaian bagi tanaman tertentu (FAO, 1976). Empat kelas kesesuaian lahan dengan spesifikasi faktor pembatas yang dinilai secara kuantitatif tersebut adalah:

1. Kelas sangat sesuai (Very suitable class) (S1)

Lahan tidak mempunyai pembatas yang berat untuk suatu penggunaan tertentu secara lestari, atau hanya pembatas yang kurang berarti dan tidak mempengaruhi secara nyata terhadap produksi lahan tersebut, serta tidak menambahkan masukan (input) dari yang biasa dilakukan dalam mengusahakan lahan.

2. Kelas cukup sesuai (Adequate suitable class) (S2)

Lahan mempunyai faktor pembatas agak berat. Berpengaruh terhadap produktivitas lahan tersebut, memerlukan tambahan masukan (input). Pembatas tersebut biasanya dapat diatasi oleh petani.

3. Kelas sesuai marginal (Marginaly suitable class) (S3)

Lahan yang mempunyai faktor pembatas sangat berat apabila dipergunakan untuk penggunaan tertentu yang lestari. Faktor pembatas ini akan berpengaruh terhadap produktivitasnya, memerlukan tambahan masukan yang lebih banyak daripada lahan yang tergolong S2. Modal tinggi diperlukan untuk mengatasi faktor pembatas pada S3.

4. Kelas tidak sesuai saat ini (N1)

Lahan yang mempunyai pembatas dengan tingkat sangat berat, akan tetapi masih memungkinkan untuk diatasi, hanya tidak dapat diperbaiki dengan tingkat pengetahuan saat ini dengan biaya yang rasional.

5. Kelas tidak sesuai permanen (N2)
Lahan yang mempunyai pembatas sangat berat, sehingga tidak mungkin untuk dipergunakan terhadap suatu penggunaan tertentu yang lestari.

Pembobotan merupakan teknik dalam pemberian nilai atau bobot untuk mengetahui besarnya pengaruh setiap faktor terhadap variabel tertentu. Pembobotan dapat dilakukan secara objektif dengan perhitungan statistik ataupun secara subjektif dengan menetapkan pertimbangan tertentu (Prasetyo, 2014). Namun, pemberian bobot pada karakteristik lahan (Djaenudin dkk., 2003) yang mengacu pada kriteria Badan Penelitian dan Pengembangan Pertanian tahun 2003 bernilai sama pengaruhnya dengan variabel lainnya dengan nilai selisih 1 .

Salah satu teknik pembobotan yang bisa digunakan adalah dengan Analisis Komponen Utama (AKU) yang dapat digunakan dalam penentuan bobot dari klasifikasi kesesuaian lahan. Tujuannya agar terlihat perbedaan pengaruh antara variabel-variabel yang ditentukan. Pembobotan berdasarkan komponen utama adalah salah satu metode yang menghasilkan validasi lebih baik diantara metode lain berdasarkan nilai korelasinya dengan peubah asal (Sumertajaya, 2005 dalam Annisa, 2014). Formula untuk menghitung bobot dengan AKU adalah:

$W_{i}=\sqrt{\frac{a_{1 i}^{2}}{\lambda_{1}}+\frac{a_{2 i}^{2}}{\lambda_{2}}+\frac{a_{3 i}^{2}}{\lambda_{3}}}$

dengan $W_{i}$ adalah bobot ke-i, $z_{i}$ adalah peubah $y_{i}$ yang sudah dibakukan, $\lambda_{i}$ adalah nilai eigen (akar ciri) ke-i, serta $a_{1}$ dan $a_{2}=$ eigen vektor ke 1 dan ke 2 yang berpadanan dengan nilai eigen (Fadli, 2012).

Selanjutnya, dilakukan normalisasi bobot yaitu dengan membagi bobot setiap variabel iklim tersebut hasil komponen utama dengan jumlah keseluruhan bobot, sehingga diperoleh total nilai sama dengan 1. Formula normalisasi bobot yang digunakan adalah berdasarkan penelitian Fernando dkk. (2012) dengan mengganti parameter korelasi menjadi parameter bobot iklim masing-masing hasil komponen utama, yaitu:

$W_{C H}=\frac{C H}{\sum_{i=1}^{n} x_{i}}$ 
Dengan $W_{C H}$ adalah bobot curah hujan normalisasi dan $x_{i}$ adalah bobot variabel iklim komponen utama ke-i.

Pembobotan yang dilakukan dalam penelitian ini adalah menggabungkan analisis subyektif dengan memberi skor dan analisis objektif dengan memberi bobot berdasarkan komponen utama menggunakan unsur curah hujan, suhu udara, tipe iklim Oldeman dan ketinggian tempat.

Nilai bobot tipe iklim Oldeman menggunakan nilai skornya karena berbentuk kriteria. Pengklasifikasian, simbol bobot, dan scoring kesesuaian agroklimat yang dibuat oleh FAO ditunjukkan pada Tabel 1.

Tabel 1. Pengklasifikasian, simbol bobot dan scoring kesesuaian agroklimat (Sumber: Djaenudin dkk., 2003)

\begin{tabular}{|c|c|c|c|c|}
\hline $\begin{array}{c}\text { Karakteristik } \\
\text { Lahan dan } \\
\text { simbol bobot }\end{array}$ & $\mathbf{4}$ & $\mathbf{3}$ & $\mathbf{2}$ & $\mathbf{1}$ \\
\cline { 2 - 5 } & & $22-24$ & $18-22$ & $<18$ \\
$\begin{array}{c}\text { Suhu udara } \\
\text { rata-rata }\left({ }^{\circ} \mathrm{C}\right) \\
(\text { Bt })\end{array}$ & $24-29$ & $29-32$ & $32-35$ & $>35$ \\
\hline $\begin{array}{c}\text { Curah Hujan } \\
\text { (mm/tahun) } \\
\text { (Bch) }\end{array}$ & $>1500$ & $\begin{array}{c}1200- \\
1500\end{array}$ & $\begin{array}{c}800- \\
1200\end{array}$ & $<800$ \\
\hline Tipe Iklim & $\mathrm{A} 1$, & $\mathrm{B} 1$, & $\mathrm{C} 1$, & $\mathrm{D} 1$, \\
\hline
\end{tabular}

\begin{tabular}{|c|c|c|c|c|}
\hline $\begin{array}{c}\text { Oldeman } \\
(\text { Bo })\end{array}$ & $\begin{array}{c}\mathrm{A} 2, \\
\mathrm{~A} 3, \mathrm{~A} 4\end{array}$ & $\begin{array}{c}\mathrm{B} 2, \\
\mathrm{~B} 3, \\
\mathrm{~B} 4\end{array}$ & $\begin{array}{c}\mathrm{C} 2, \\
\mathrm{C} 3, \mathrm{C} 4\end{array}$ & $\begin{array}{c}\mathrm{D} 2, \\
\mathrm{D} 3, \\
\mathrm{D} 4, \mathrm{E}\end{array}$ \\
\hline $\begin{array}{c}\text { Ketinggian } \\
\begin{array}{c}\text { Tempat } \\
(\mathbf{B h})\end{array}\end{array}$ & $\begin{array}{c}<500 \\
\mathrm{~m}\end{array}$ & $\begin{array}{c}<750 \\
\mathrm{~m}\end{array}$ & $\begin{array}{c}<1000 \\
\mathrm{~m}\end{array}$ & $\begin{array}{c}>1000 \\
\mathrm{~m}\end{array}$ \\
\hline
\end{tabular}

Selanjutnya dilakukan perkalian nilai skor dari masing masing unsur tersebut dengan nilai bobot hasil analisis komponen utama. Kemudian, menjumlahkan skor akhir masingmasing unsur untuk mendapatkan tingkat kesesuaian agroklimat tanaman padi. Berikut adalah formula untuk mendapatkan skor akhir:

Skor akhir $=(B t \times$ Score $B t)+$

$(B c h \times$ Score $B c h)+(B o \times$

Score Bo $)+(B h \times$ Score $B h)$

dengan Bt adalah bobot suhu udara rata-rata, Bch adalah bobot curah hujan, Bo adalah bobot Oldeman, dan $\mathrm{Bh}$ adalah bobot ketinggian yang masing-masing adalah hasil normalisasi bobot AKU.

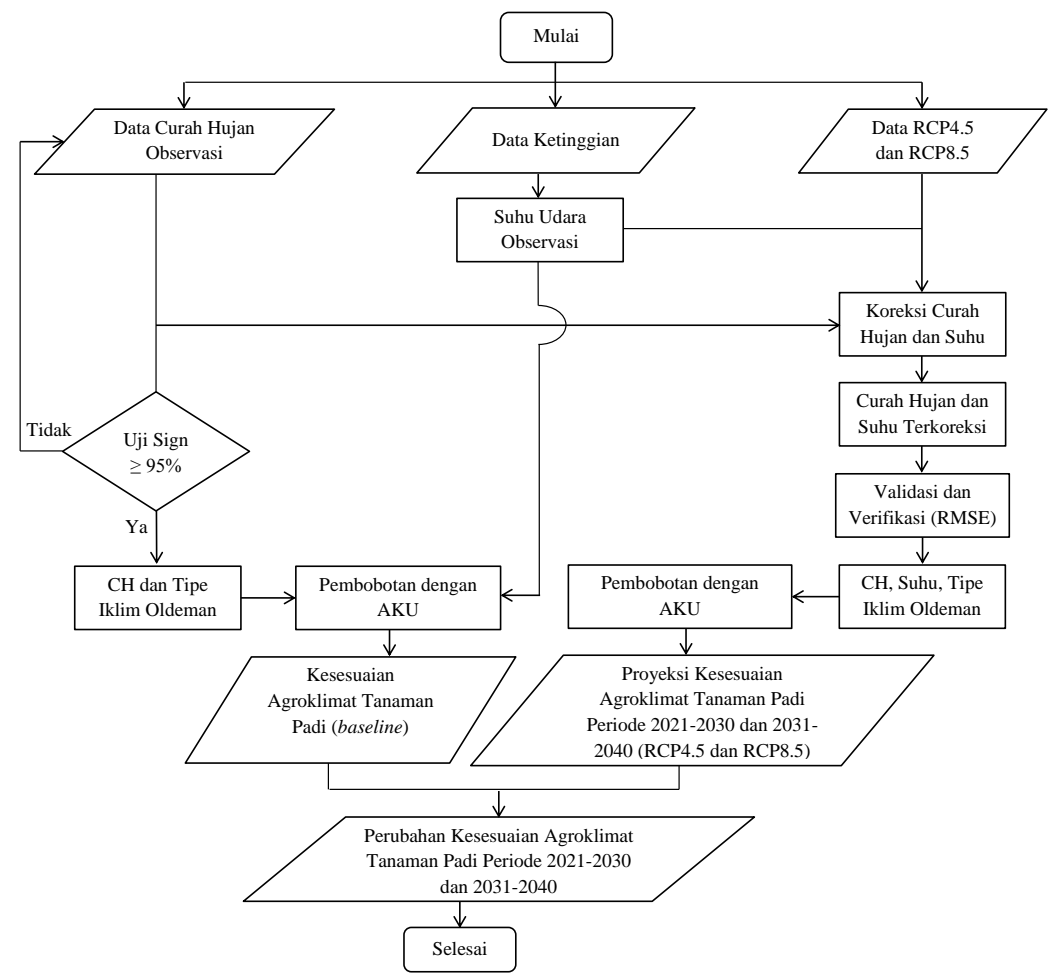

Gambar 1. Diagram alir. 
Kemudian, membuat kelas skor akhir untuk menentukan empat klasifikasi kesesuaian agroklimat tanaman padi, yaitu S1, S2, S3 dan $\mathrm{N}$ dimana kelas skor dengan paling kecil diklasifikasikan ke dalam $\mathrm{N}$ dan kelas skor yang paling besar diklasifikasikan ke dalam S1. Formula untuk menghitung lebar kelas skor (Sudjana, 2009) adalah sebagai berikut:

Lebar Kelas $=\frac{\text { Data Maksimum-Data Minimum }}{\text { Banyaknya kelas }}$

\section{HASIL DAN PEMBAHASAN}

Variabel iklim yang digunakan untuk menentukan bobot dalam analisis komponen utama berupa jumlah curah hujan tahunan, suhu udara rata-rata tahunan, tipe iklim Oldeman dan ketinggian tempat dari seluruh ZOM di Jawa Timur. Tipe iklim Oldeman yang dihasilkan masih dalam bentuk karakter (misal: B1), sehingga untuk running PCA digunakan nilai skornya sebagai konversi dan hasilnya disajikan pada Tabel 2. Nilai eigen pada setiap komponen utama yang $\geq 1$ adalah komponen utama pertama dan kedua dengan nilai 2.7084 dan 1.0413 dengan proporsi keragaman data yang dapat dijelaskan berturut-turut adalah $67.7 \%$ dan $26 \%$.

Tabel 2. Analisis Komponen Utama (PCA) variabel iklim

\begin{tabular}{|l|c|c|c|c|}
\hline Eigenvalue & 2.7084 & 1.0413 & 0.2336 & 0.0167 \\
\hline Proportion & 0.677 & 0.26 & 0.058 & 0.004 \\
\hline Cumulative & 0.677 & 0.937 & 0.996 & 1 \\
\hline & & & & \\
\hline Variabel & PC1 & PC2 & PC3 & PC4 \\
\hline Curah Hujan & 0.494 & 0.448 & -0.745 & 0.022 \\
\hline Suhu Udara & -0.543 & 0.428 & -0.124 & -0.712 \\
\hline $\begin{array}{l}\text { Tipe Iklim } \\
\text { Oldeman }\end{array}$ & 0.431 & 0.616 & 0.655 & -0.072 \\
\hline Ketinggian & 0.525 & -0.486 & 0.035 & -0.698 \\
\hline
\end{tabular}

Jika dikumulatifkan, komponen utama dengan keragaman data lebih dari $80 \%$ sudah dapat dijelaskan dengan dua komponen saja yaitu PC1 dan PC2. Pada kasus ini, digunakan empat komponen utama yang dihasilkan karena tidak melakukan proses regresi yang berpengaruh pada hasil prakiraan tetapi hanya sampai analisis komponen utamanya saja untuk digunakan dalam pembobotan.

Tabel 3. Nilai bobot hasil running PCA

\begin{tabular}{|c|c|c|c|c|c|}
\hline Jenis Bobot & CH & Suhu & Oldeman & Ketinggian & Total \\
\hline Bobot PCA & 1.64 & 5.54 & 3.23 & 1.07 & 11.48 \\
\hline Bobot akhir & 0.14 & 0.48 & 0.28 & 0.09 & 1 \\
\hline
\end{tabular}

Dari tabel diatas, dapat dilihat bahwa berdasarkan analisis komponen utama, bobot yang paling besar diberikan oleh suhu udara, yaitu 5.54 diikuti oleh tipe iklim Oldeman sebesar 3.23, serta curah hujan dan ketinggian memiliki bobot yang paling kecil secara berturut berkisar 16.4 dan 1.07. Hal ini berarti pengaruh yang paling besar terhadap penentuan kesesuaian agroklimat tanaman padi diberikan oleh suhu udara sedangkan curah hujan memiliki pengaruh yang lebih kecil. Setelah mendapatkan nilai skor akhir, maka interval kelas skor akhir kesesuaian agroklimat tanaman padi dapat disajikan pada Tabel 4.

Tabel 4. Kelas skor akhir kesesuaian agroklimat tanaman padi

\begin{tabular}{|c|c|c|}
\hline No. & Interval & Kelas \\
\hline 1 & $1.08-1.74$ & $\mathrm{~N}$ \\
\hline 2 & $1.75-2.40$ & $\mathrm{~S} 3$ \\
\hline 3 & $2.41-3.06$ & $\mathrm{~S} 2$ \\
\hline 4 & $3.07-3.72$ & $\mathrm{~S} 1$ \\
\hline
\end{tabular}

Selanjutnya, kelas skor akhir diatas digunakan untuk membuat peta kesesuaian agroklimat pada periode saat ini (baseline) seperti yang disajikan pada Gambar 1, semua periode masa depan dibawah skenario RCP4.5 dan RCP8.5 sehingga dapat dianalisis perubahannya terhadap periode sekarang.

Kesesuaian pada kondisi sekarang yang menunjukkan umumnya di Jawa Timur didominasi oleh keadaan yang sangat sesuai (S1) dengan sebaran yang merata pada bagian timur Jawa Timur hingga ke bagian barat. Sedangkan sebaran dengan keadaan yang cukup sesuai (S2) berada pada daerah dekat pesisir tenggara, timur hingga ke utara serta hampir seluruh Pulau Madura. Hanya ada 1 ZOM yang mengalami kesesuaian yang marginal (S3) dan tidak sesuai (N) untuk menanam padi berdasarkan kondisi iklimnya, yaitu secara berturut ZOM 147 dan ZOM 186. 
Gambar 2 merupakan kesesuaian agroklimat dibawah skenario RCP4.5 pada periode Future 1 (2021-2030) yang menunjukkan kondisi yang tidak jauh berbeda dari periode sekarang, kecuali ZOM 147 yang berubah kesesuaiannya dari S3 menjadi S2. Sebagian besar Pulau Madura menunjukkan peningkatan kesesuaian menjadi sangat sesuai, beberapa ZOM di wilayah Jawa Timur bagian timur mengalami pengurangan tingkat kesesuaian S2 dan didominasi oleh keadaan yang sangat sesuai. Sedangkan ZOM 186 tetap berada pada keadaan yang tidak sesuai iklimnya untuk ditanami padi sawah.
Jika dibandingkan dengan proyeksi pada periode yang sama dibawah skenario RCP8.5 (Gambar 3), umumnya sebaran kesesuaian S1 masih mendominasi tetapi tidak sebanyak yang diproyeksikan oleh RCP4.5. Tingkat kesesuaian S2 tersebar pada wilayah dekat pesisir timur hingga utara Jawa Timur serta sebagian besar Pulau Madura. Terdapat penambahan $1 \mathrm{ZOM}$ dengan kondisi sesuai marginal dari proyeksi RCP4.5, yaitu ZOM 202 dan kondisi yang tidak sesuai masih tetap dialami oleh ZOM 186.

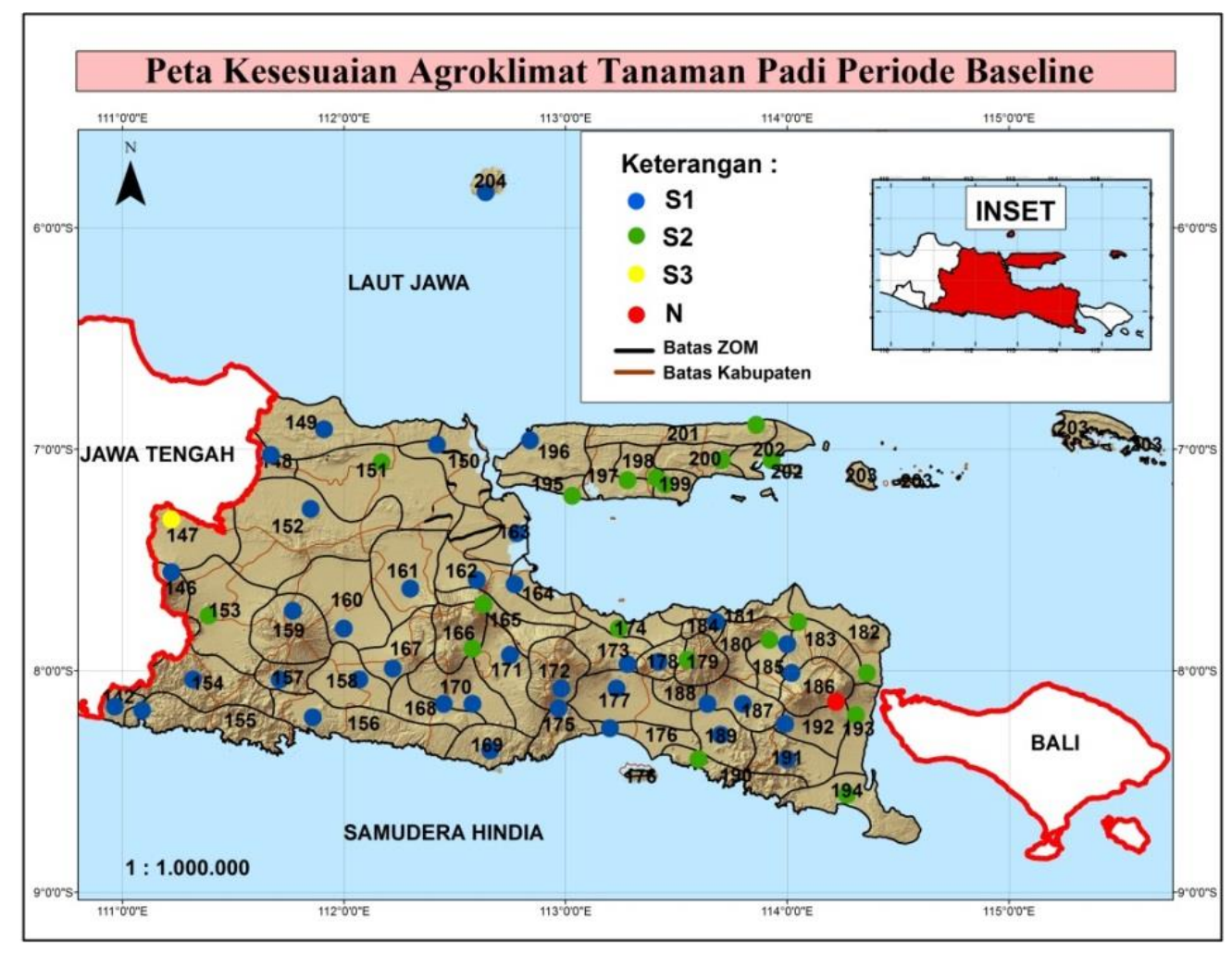

Gambar 1. Peta kesesuaian agroklimat tanaman padi periode baseline (1996-2005) ZOM Jawa Timur 


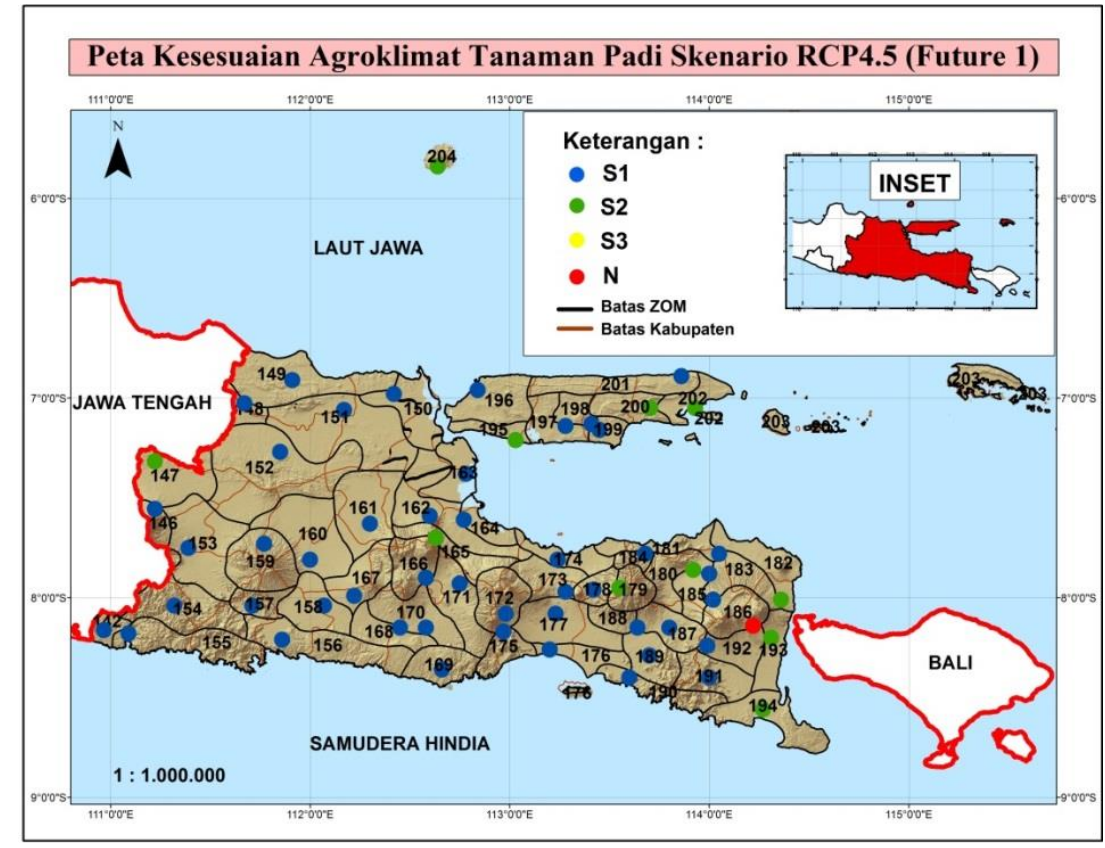

Gambar 2. Peta kesesuaian agroklimat tanaman padi Skenario RCP4.5 periode Future 1 (2021-2030) ZOM Jawa Timur

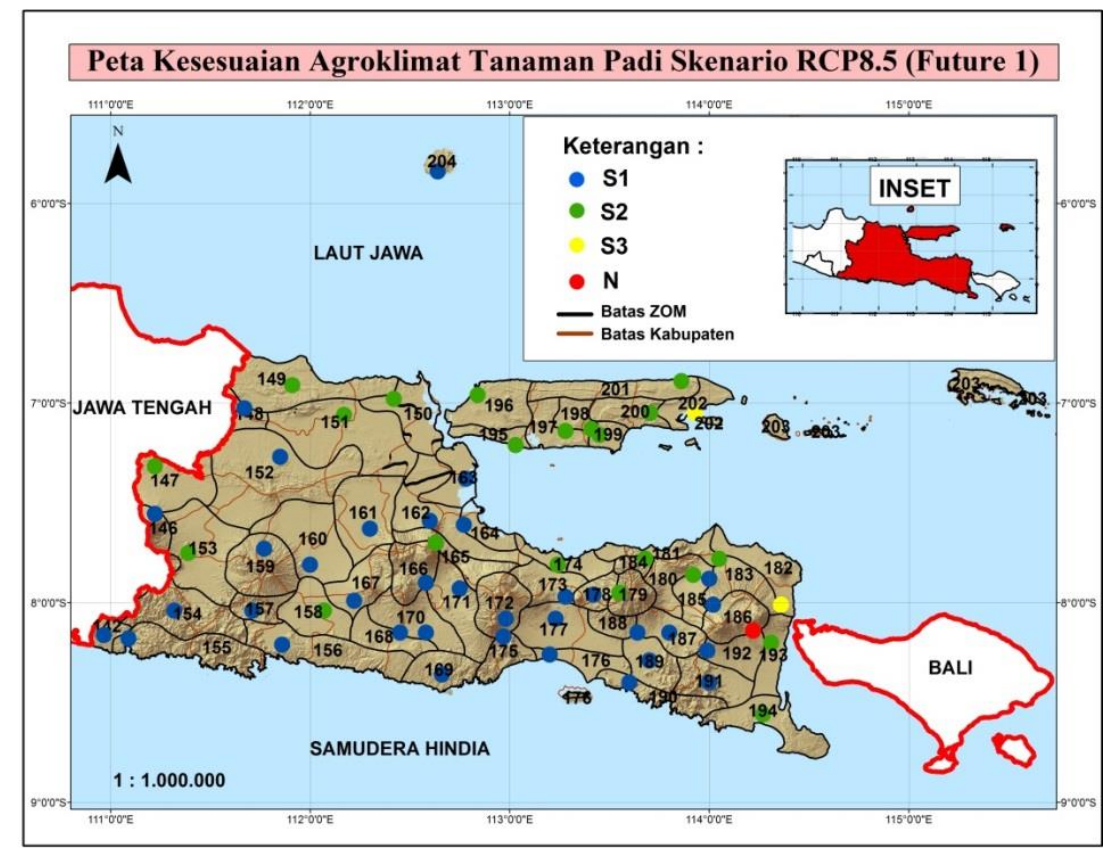

Gambar 3. Peta kesesuaian agroklimat tanaman padi Skenario RCP8.5 periode Future 1 (2021-2030) ZOM Jawa Timur 


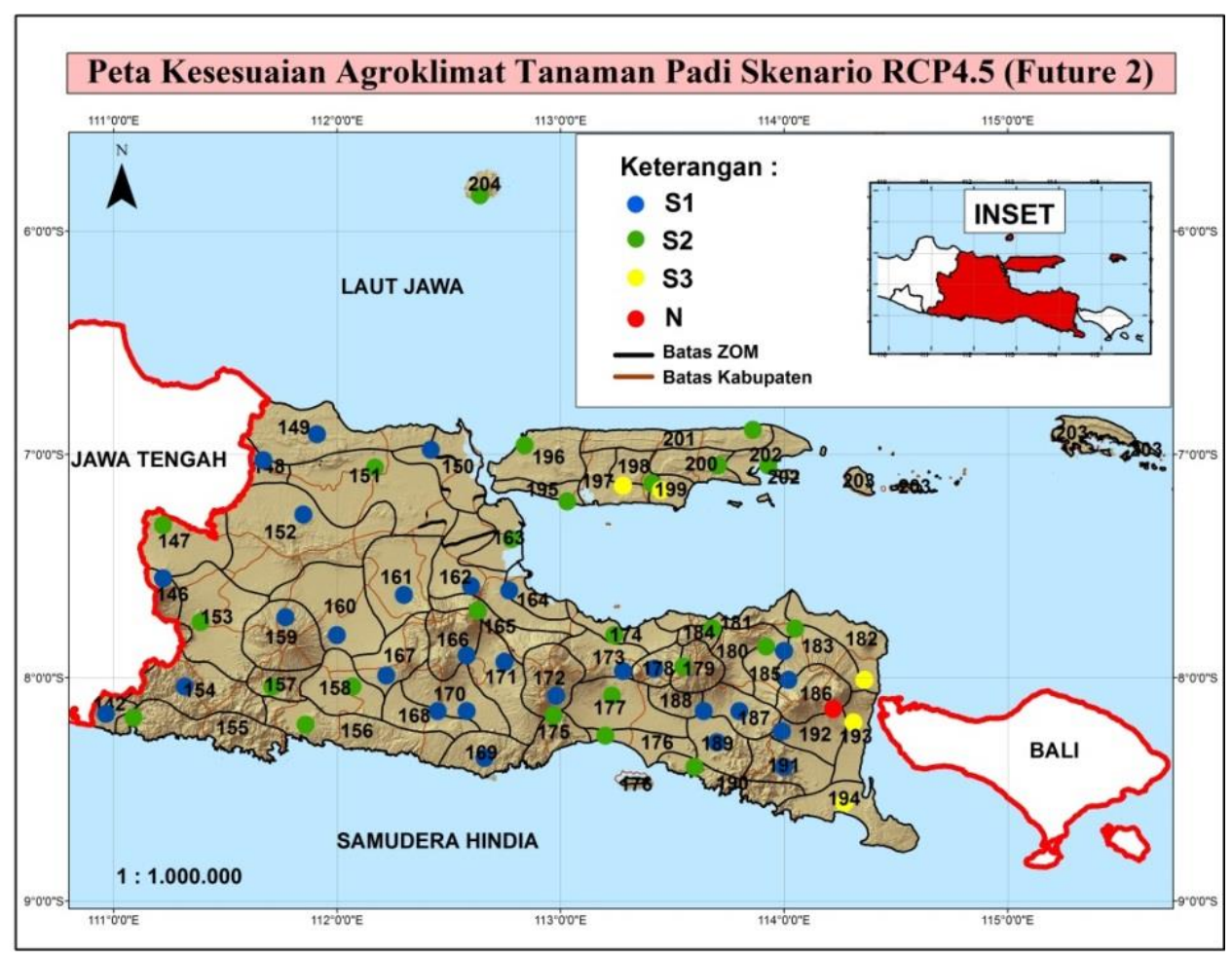

Gambar 4. Peta kesesuaian agroklimat tanaman padi Skenario RCP4.5 periode Future 2 (2031-2040) ZOM Jawa Timur.

Perubahannya terhadap kondisi sekarang, skenario ini memproyeksikan kondisi S2 menjadi lebih banyak dan terdapat penambahan 2 ZOM yang sesuai marginal. Gambar 4 merupakan kesesuaian agroklimat dibawah skenario RCP4.5 pada periode Future 2 (2031-2040) yang menunjukkan kondisi sangat berbeda dari kondisi sekarang, khususnya terdapat penambahan ZOM yang mengalami kondisi sesuai marginal (S3) dan berpusat pada pesisir timur Jawa Timur serta pesisir selatan Pulau Madura. Sedangkan pada periode sebelumnya, menunjukkan tidak adanya kesesuaian yang marginal, bahkan kondisi yang sebelumnya S1 langsung menjadi S3 pada periode ini.
Jika dibandingkan dengan proyeksi dibawah skenario RCP8.5 (Gambar 5), umumnya tidak memiliki perbedaan yang signifikan, kecuali pada ZOM 147 yang berubah dari kondisi S2 menjadi S3 dan ZOM 193 menunjukkan keadaan yang sebaliknya dari kondisi S3 menjadi S2. Terdapat penambahan ZOM yang memiliki kondisi tidak sesuai kondisi iklimnya untuk menanam padi, yaitu ZOM 202 yang sebelumnya dengan skenario paling pesismis, memiliki kondisi yang sesuai marginal. Apabila dilihat perbandingannya dengan kondisi sekarang, kondisi ini merupakan yang terparah tingkat perubahannya. 


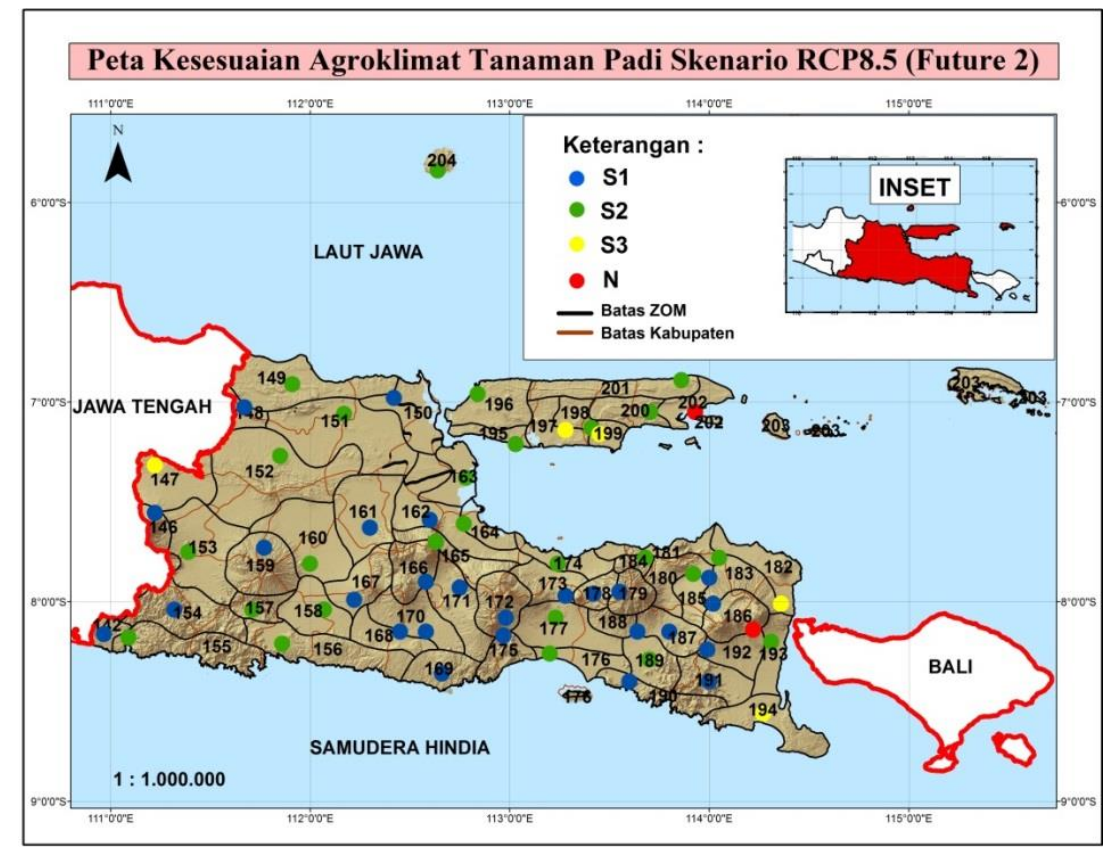

Gambar 5. Peta kesesuaian agroklimat tanaman padi Skenario RCP8.5 periode Future 2 (2031-2040) ZOM Jawa Timur

Sebaran kesesuaian agroklimat tanaman padi pada periode sekarang (baseline) di ZOM Jawa Timur yang didominasi oleh keadaan yang sangat sesuai dikarenakan tipe iklim Oldemannya termasuk kategori yang basah dengan bulan basah berturut 5-6 bulan. Hal ini memungkinkan petani untuk melakukan 1 kali masa tanam padi sawah karena masih tersedia pasokan air hujan tanpa mempertimbangkan jenis tanahnya. Sedangkan, Pulau Madura menunjukkan kesesuaian yang cukup pada periode ini, walaupun tipe iklim Oldemannya umumnya $\mathrm{E}$ dan curah hujan tahunannya sangat rendah. Hal ini disebabkan suhu udara dan ketinggian tempat memberikan skor dan bobot yang tinggi atau ideal terhadap pertumbuhan padi sawah. ZOM 147 mengalami kesesuaian yang marginal dikarenakan skor untuk ketinggian tempat sangat kecil, artinya wilayah tidak mendukung untuk menanam padi pada tempat yang terlalu tinggi.

Hal ini juga terjadi dan berlaku untuk kesesuaian agroklimat pada periode 20212030. Pada periode tersebut, dibawah skenario RCP4.5 kesesuaian justru menjadi semakin sesuai, karena skenario ini memproyeksikan terjadinya peningkatan curah hujan tahunan dan keadaan suhu yang ideal untuk tanaman padi di Jawa Timur. Sebaliknya, dibawah skenario RCP8.5 terdapat penambahan 2 ZOM dengan tingkat kesesuaian yang marginal dikarenakan adanya peningkatan suhu udara rata-rata sebesar $1^{\circ} \mathrm{C}$ yang dapat menurunkan tingkat kesesuaian. Khusus untuk ZOM 202, diproyeksikan mengalami penuruan pasokan air hujan terhadap kondisi saat ini yang akan mempengaruhi pertumbuhan tanaman padi.

Selanjutnya, untuk periode proyeksi 20312040 menunjukkan keadaan yang semakin parah atau terjadi peningkatan keadaan iklim yang tidak sesuai untuk menanam padi sawah. Dibawah skenario RCP4.5 terdapat $5 \mathrm{ZOM}$ yang mengalami kesesuaian iklim marginal (bertambah 4 ZOM terhadap kondisi saat ini). Bila dilihat ketinggian tempat merupakan tempat yang ideal bagi padi sawah dan tipe iklim Oldeman pada keempat ZOM tersebut tidak berubah terhadap kondisi saat ini (bertipe iklim E). Hal ini disebabkan oleh peningkatan suhu udara kecuali ZOM 193 dan 194 yang dikarenakan peningkatan curah hujan tahunan dari kondisi idealnya.

Dibawah skenario RCP8.5 juga mengalami kondisi yang sama dengan proyeksi RCP4.5, kecuali untuk ZOM 202 serta terdapat penambahan kondisi iklim yang sesuai marginal di ZOM 147 terhadap periode 2021- 
2030. ZOM 202 menjadi tidak sesuai diakibatkan peningkatan suhu sebesar hampir $2^{\circ} \mathrm{C}$ terhadap kondisi saat ini dan $0.3^{\circ} \mathrm{C}$ terhadap periode sebelumnya, selain didukung dengan tipe iklim yang kering. ZOM 147 kembali pada kondisi iklim saat ini dikarenakan tipe iklim Oldemannya juga kembali menjadi tipe iklim $\mathrm{C}$ selain didukung ketinggian tempat yang tidak ideal.

Wilayah ZOM 186 menunjukkan trend curah hujan yang signifikan, yaitu penurunan curah hujan sebesar $3.6 \mathrm{~mm} / \mathrm{tahun}$. Selanjutnya, curah hujan tahunan kondisi saat ini dan periode proyeksi menunjukkan kondisi iklim yang ideal. Tetapi, tipe iklim Oldeman tidak memberikan dukungan karena sangat kering untuk menanam padi.

Suhu udara rata-rata tahunan sepanjang periode juga menunjukkan suhu yang terlalu rendah. Ketinggian titik yang mewakili ZOM ini juga terlalu tinggi, yaitu 2212 meter. Sehingga, pada semua periode ZOM 186 adalah satu-satunya yang menunjukkan kondisi iklim yang tidak sesuai untuk menanam padi. Hal ini relevan dengan penelitian Fauziah (2016) yang menyatakan bahwa faktor ketinggian sebagai faktor penunjang (non-iklim) yang merupakan salah satu pembatas yang paling berpengaruh dalam menentukan tingkat/kelas kesesuaian. Ketinggian ekstrim akan diikuti oleh suhu yang rendah, sehingga kedua parameter berpengaruh pada penurunan jumlah skor kelas kesesuaian.

Namun, berdasarkan analisis komponen utama pengaruh terbesar diberikan oleh suhu udara dan tipe iklim Oldeman, sedangkan curah hujan tahunan dan ketinggian berperan sangat kecil. Terbukti pada analisis diatas bahwa penyebab menurun dan meningkatnya tingkat kesesuaian baik terhadap kondisi sekarang maupun periode proyeksi sebelumnya pada kedua skenario adalah suhu udara dan tipe iklim Oldemannya.

Fauziah (2016) juga menyatakan bahwa perubahan tingkat kesesuaian diakibatkan oleh perubahan nilai dari masing-masing parameter pada tiap periode baik secara signifikan maupun tidak. Hasil trend variabel iklim yang tidak signifikan menyebabkan hasil perubahan tingkat kesesuaian agroklimat yang tidak signifikan pula. Namun, hal tersebut hanya berlaku untuk ZOM 147 sedangkan ZOM yang signifikan lainnya tidak menunjukkan perubahan yang signifikan. Justru, ZOM yang tidak mengalami perubahan variabel iklim yang signifikan menunjukkan perubahan tingkat kesesuaian yang signifikan seperti yang terjadi pada ZOM 202. Sehingga, signifikansi perubahan tingkat kesesuaian agroklimat tidak bergantung pada signifikansi trend variabel iklim, tetapi pada seberapa besar peningkatan variabel iklim di wilayah masing-masing dibawah skenario iklim.

Tabel 3. Nilai bobot hasil running PCA

\begin{tabular}{|c|c|c|c|c|c|}
\hline \multirow[b]{2}{*}{ Ket. } & \multirow{2}{*}{\begin{tabular}{|c} 
Baseline \\
$1996-$ \\
2005
\end{tabular}} & \multicolumn{2}{|c|}{ RCP4.5 } & \multicolumn{2}{|c|}{ RCP8.5 } \\
\hline & & $\begin{array}{c}\text { Future } \\
1\end{array}$ & $\begin{array}{c}\text { Future } \\
2\end{array}$ & $\begin{array}{c}\text { Future } \\
1\end{array}$ & $\begin{array}{c}\text { Future } \\
2\end{array}$ \\
\hline S1 & $64 \%$ & $80 \%$ & $47 \%$ & $59 \%$ & $44 \%$ \\
\hline S2 & $32 \%$ & $19 \%$ & $42 \%$ & $36 \%$ & $44 \%$ \\
\hline S3 & $2 \%$ & $0 \%$ & $8 \%$ & $3 \%$ & $8 \%$ \\
\hline $\mathrm{N}$ & $2 \%$ & $2 \%$ & $2 \%$ & $2 \%$ & $3 \%$ \\
\hline Total & $100 \%$ & $100 \%$ & $100 \%$ & $100 \%$ & $100 \%$ \\
\hline
\end{tabular}

Berdasarkan tabel diatas, jumlah ZOM di Jawa Timur yang kondisi iklimnya sesuai pada semua periode adalah yang paling banyak dengan perubahan yang meningkat pada periode Future 1 dibawah skenario RCP4.5 dan menurun di bawah skenario RCP8.5. Sedangkan di Future 2 kedua skenario memproyeksikan penurunan jumlah ZOM terhadap kondisi sekarang. Kondisi iklim yang cukup sesuai dialami oleh $32 \%$ dari ZOM Jawa Timur pada kondisi sekarang dan mengalami penurunan jumlah ZOM pada semua periode proyeksi kecuali pada Future 1 dibawah RCP8.5.

Kondisi iklim yang sesuai marginal dan tidak sesuai terjadi di $2 \%$ dari jumlah ZOM di Jawa Timur. Kesesuaian agroklimat yang marginal, diproyeksikan akan mengalami peningkatan jumlah ZOM kecuali pada periode Future 1 dibawah skenario RCP4.5. Sedangkan keadaan iklim yang tidak sesuai untuk menanam padi selalu tetap $2 \%$ dari jumlah ZOM dan meningkat pada periode Future 2 dibawah skenario RCP8.5.

Perubahan tingkat kesesuaian agroklimat tanaman padi di Jawa Timur utamanya disebabkan oleh perubahan suhu udara hasil simulasi khususnya dibawah skenario RCP4.5 
pada Future 1. Fauziah (2016) menyatakan bahwa peningkatan jumlah $\mathrm{S} 1$ terjadi di wilayah dataran tinggi yang menunjukkan suhu awal lebih rendah atau berada pada kelas rendah (bobot kecil). Sehingga, suhu udara pada periode selanjutnya masuk pada kelas yang lebih tinggi (bobot yang lebih besar) mempengaruhi nilai skor akhir. Sebaliknya, penurunan jumlah S1 pada Future 2 terjadi pada dataran rendah yang pada dasarnya memiliki suhu tinggi. Karena proyeksi RCP4.5 menunjukkan hasil peningkatan suhu udara, suhu udara yang sudah tinggi menjadi keluar ambang batas S1.

Hal ini juga terjadi pada periode Future 1 dibawah skenario RCP8.5 dengan tingkat kesesuaian agroklimat yang cukup sesuai. Namun, perubahannya tidak besar karena diimbangi oleh meningkatnya suhu udara yang lebih tinggi dari skenario RCP4.5 di wilayah dataran tinggi (ZOM 147 dan ZOM 186).

\section{KESIMPULAN}

Kesesuaian agroklimat tanaman padi pada periode sekarang (baseline) di Provinsi Jawa Timur didominasi oleh tingkat kesesuaian yang sangat sesuai atau S1 (64 \%) dan cukup sesuai atau S2 (32 \%). Sedangkan hanya $2 \%$ dari wilayah ZOM dengan kondisi iklim yang sesuai marginal atau S3 dan tidak sesuai atau $\mathrm{N}$ berturut-turut, yaitu ZOM 147 dan ZOM 186.

Skenario RCP8.5 memproyeksikan kesesuaian agroklimat lebih signifikan dibandingkan RCP4.5 hingga tahun 2040 di Provinsi Jawa Timur. Hal ini dibuktikan dengan bertambahnya ZOM yang memiliki tingkat kesesuaian agroklimat yang tidak sesuai atau $\mathrm{N}$, yaitu ZOM 202. Hasil simulasi dengan skenario RCP4.5 pada periode Future 1 terhadap periode baseline menambah tingkat kesesuaian S1 sebesar $16 \%$ dan mengurangi S2 sebesar $13 \%$ sedangkan tingkat sesuai marginal atau S3 menjadi tidak ada dan kondisi tidak sesuai atau $\mathrm{N}$ adalah tetap.

Sedangkan, pada periode Future 2 terhadap periode baseline kondisi S1 menjadi berkurang sebesar $17 \%$ dan menambah S2 dan $\mathrm{S} 3$ sebesar $10 \%$ dan $5 \%$, serta $\mathrm{N}$ adalah tetap. Sehingga, pada periode Future 1 tidak menjadi halangan bagi petani untuk melakukan pembudidayaan serta pengembangan tanaman padi di Jawa Timur, kecuali pada ZOM 186. Namun, pada periode Future 2 petani memerlukan tambahan masukan baik irigasi maupun teknologi lainnya khususnya pada ZOM 182, 193, 194, 197 dan 199.

Hasil simulasi dengan skenario RCP8.5 pada periode Future 1 terhadap periode baseline mengurangi kondisi $\mathrm{S} 1$ sebesar $5 \%$ dan menambah kondisi S2 dan S3 sebesar $4 \%$ dan $1 \%$ serta $\mathrm{N}$ adalah tetap. Sedangkan, pada periode Future 2 terhadap periode baseline mengurangi kondisi S1 sebesar $20 \%$, menambah kondisi S2, S3 dan N sebesar 12 $\%, 6 \%$ dan $1 \%$. Dibawah skenario dengan usaha paling pesimis untuk menurunkan emisi GRK, faktor iklim menjadi halangan bagi petani di Jawa Timur sehingga memerlukan tambahan masukan baik irigasi maupun teknologi, khususnya di ZOM 202 dan 182 pada periode Future 1 serta ZOM 147, 182, 194, 197, dan 199 pada periode Future 2.

Model yang digunakan dalam penelitian ini hanya satu model sehingga belum cukup memberikan gambaran kondisi iklim di masa depan. Perlu masukan banyak model lain dengan resolusi yang sama untuk melihat kemungkinan di masa depan dengan berbagai range ketidakpastiannya.

\section{DAFTAR PUSTAKA}

Annisa. 2014. Penerapan AMMI Respon Ganda dengan Pembobotan Komponen Utama pada Uji Stabilitas Tanaman Kumis Kucing. Skripsi. Institut Pertanian Bogor. http://repository.ipb.ac.id/handle/12345 $6789 / 71818$

Badan Penelitian dan Pengembangan Pertanian Kementrian Pertanian. 2011. Pedoman Umum Adaptasi Perubahan Iklim Sektor Pertanian. Badan Penelitian dan Pengembangan Pertanian. Jakarta.

BPS. 2015. Data Produksi Padi Provinsi Jawa Timur. http://www.bps.go.id/ diakses pada 10 November 2016.

Braak C. 1928. The Climate of The Netherlands Indies. Proc. Royal Mogn. Meteor.Observ. Batavia, nr. 14. pp. 192. 
Djaenudin, D, H., Marwan, H., Subagjo, dan Hidayat, A. 2003. Petunjuk Teknis Evaluasi Lahan untuk Komoditas Pertanian. Bogor : Balai Penulisan dan Pengembangan Pertanian. Bogor.

Fadli, G.Z. 2012. Penerapan pembobotan Komponen Utama Untuk Pereduksian Peubah Pada Additive Main Effect And Multiplicative Interaction. Skripsi. Institut Pertanian Bogor. http://repository.ipb.ac.id/handle/12345 6789/54671.

FAO. 1976. A Framework for Land Evalution. FAO Soil BuletinNo.32. Wageningen : ILRI.

Fauziah, A.R. 2016. Proyeksi Kesesuaian Agroklimat Tanaman Padi Berdasarkan Skenario Representative Concentration Pathways (RCP) 4.5 Di Provinsi Jawa Tengah. Skripsi. Klimatologi. Sekolah Tinggi Meteorologi Klimatologi dan Geofisika. Jakarta.

Fernando, M., Samita, S. dan Abeynayake, R., (2012). Modified Factor Analysis to Construct Composite Indices: Illustration on Urbanization Index. Tropical Agricultural Research. 23(4), pp.327-337.

DOI: http://doi.org/10.4038/tar.v23i4.4868

IPCC. 2007. Climate Change 2007: Synthesis Report. Intergovernmental Panel on Climate Change.Cambridge University Press, New York.

IPCC. 2013. Climate Change 2013: The Physial science Basis. Contribution of

\section{LAMPIRAN}

Lampiran 1(a)

Daftar Wilayah Penelitian ZOM Jawa Timur
Working Group I to the Fifth Assesment Report if Intergovermental Panel on Climate Change [ Stocker,T.F, D. Qin, G.-K. Plattner,M. Tignor, S.K. Allen, J. Boschung, A. Nauels, Y. Xia, V. Bex and P.M. Midgley (eds)]. Cambridge University Press, Cambridge, United Kingdom and New York, NY, USA.

Kandari, A.M, Baja, S., Ala, A., dan Kaimuddin. 2013. Agroecological Zoning and Land Suitability Assessment for Maize (Zea Mays L.) Development in Buton Regency, Indonesia. Agriculture, Forestry and Fisheries Vol.2, No.6, 2013, pp.202211. Doi: 10.11648/j.aff.20130206.11.

Prasetyo, R.B. 2014. Analisis Spasial pada Aglomerasi Industri Manufaktur di Pulau Jawa. Skripsi. FMPI ITS. Surabaya.

Sudjana. 2009. Metoda Statistika. Bandung : PT. Tarsito Bandung.

Trenberth, K.E., Dai, A., Rasmussen, R.M., dan Parsons, D.B. 2003. The Changing Character of Precipitation. American Meteorological Society. http://journals.ametsoc.org/ diakses tanggal 16 Desember 2016.

Weiland, F. C. S., Van Beek L. P. H., Kwadijk, J. C. J., dan Bierkens, M. F. P. 2010. The Ability of A GCM-Forced Hydrological Model to Reproduce Global Discharge Variability. Hydrology and Earth System Science Journal 14, p. 1595-1621.

\begin{tabular}{|c|c|c|c|c|}
\hline ZOM & $\begin{array}{c}\text { Pos Hujan/ } \\
\text { Stasiun } \\
\text { Pengamatan* }\end{array}$ & Bujur & Lintang & Ketinggian (m) \\
\hline 149 & Kerek & 111.91 & -6.91 & 99 \\
\hline 150 & Lowayu & 112.42 & -6.98 & 28 \\
\hline 151 & Widang & 112.17 & -7.06 & 39 \\
\hline 152 & Dander & 111.85 & -7.27 & 62 \\
\hline 153 & Lembeyan & 111.39 & -7.75 & 156 \\
\hline 154 & Tegalombo & 111.32 & -8.04 & 222 \\
\hline 155 & PU Pacitan & 111.09 & -8.18 & 275 \\
\hline 156 & Tumpakmergo & 111.86 & -8.21 & 121 \\
\hline 157 & Dam Bagong & 111.71 & -8.04 & 129 \\
\hline 158 & Srengat & 112.07 & -8.04 & 675 \\
\hline $159^{*}$ & Stageof Sawahan & 111.77 & -7.73 & 69 \\
\hline 160 & PU Kediri & 112.00 & -7.81 & \\
\hline
\end{tabular}




\begin{tabular}{|c|c|c|c|c|}
\hline 161 & Mojowarno & 112.30 & -7.63 & 82 \\
\hline 162 & Janjing & 112.60 & -7.59 & 216 \\
\hline $163 *$ & Stamet Juanda & 112.78 & -7.38 & 2.8 \\
\hline 164 & Bangil & 112.77 & -7.61 & 23 \\
\hline $165 *$ & Stageof Tretes & 112.63 & -7.70 & 832 \\
\hline ZOM & $\begin{array}{c}\text { Pos Hujan / } \\
\text { Stasiun } \\
\text { Pengamatan* }\end{array}$ & Bujur & Lintang & Ketinggian (m) \\
\hline $166^{*}$ & $\begin{array}{c}\text { Staklim } \\
\text { Karangploso }\end{array}$ & 112.58 & -7.90 & 575 \\
\hline 167 & Kalibadak & 112.22 & -7.99 & 566 \\
\hline $168 *$ & $\begin{array}{c}\text { Stageof } \\
\text { Karangkates }\end{array}$ & 112.45 & -8.15 & 285 \\
\hline 169 & Sitiarjo & 112.66 & -8.36 & 32 \\
\hline 170 & Karangsuko & 112.58 & -8.15 & 352 \\
\hline 171 & Jabung & 112.75 & -7.93 & 530 \\
\hline 172 & Senduro & 112.98 & -8.08 & 451 \\
\hline 173 & Ranuklakah & 113.28 & -7.97 & 267 \\
\hline 174 & Sumberbuluh & 113.24 & -7.81 & 53 \\
\hline 175 & Supiturang & 112.97 & -8.17 & 721 \\
\hline 176 & Maleman & 113.20 & -8.26 & 18 \\
\hline 177 & Sukodono & 113.23 & -8.08 & 65 \\
\hline 178 & Tiris & 113.42 & -7.96 & 506 \\
\hline 179 & Bermi & 113.55 & -7.95 & 926 \\
\hline 180 & Glendengan & 114.00 & -7.88 & 128 \\
\hline 181 & Cerme & 114.05 & -7.78 & 103 \\
\hline 182 & Alas Buluh & 114.36 & -8.01 & 42 \\
\hline 183 & Sumbergading & 114.02 & -8.01 & 659 \\
\hline 184 & Jatibanteng & 113.68 & -7.78 & 90 \\
\hline 185 & Dam Jeru & 113.92 & -7.86 & 212 \\
\hline ZOM & $\begin{array}{c}\text { Pos Hujan / } \\
\text { Stasiun } \\
\text { Pengamatan* }\end{array}$ & Bujur & Lintang & Ketinggian(m) \\
\hline 186 & Kawah Ijen & 114.22 & -8.14 & 2212 \\
\hline 187 & Jatian & 113.80 & -8.15 & 218 \\
\hline 188 & Dam Pono & 113.64 & -8.15 & 154 \\
\hline 189 & Tempurejo & 113.70 & -8.29 & 83 \\
\hline 190 & Sumberejo & 113.60 & -8.40 & 97 \\
\hline 191 & Terbasala & 114.00 & -8.40 & 260 \\
\hline 192 & Gunung Raung & 113.99 & -8.24 & 650 \\
\hline $193 *$ & Stamet Banyuwangi & 114.31 & -8.20 & 34 \\
\hline 194 & Grajagan & 114.27 & -8.56 & 37 \\
\hline 195 & Tegaldlimo & 113.03 & -7.21 & 56 \\
\hline 196 & Arosbaya & 112.84 & -6.96 & 35 \\
\hline 197 & Sampang & 113.28 & -7.14 & 22 \\
\hline 198 & Propo & 113.41 & -7.13 & 65 \\
\hline 199 & Samiran & 113.45 & -7.16 & 37 \\
\hline 200 & Ganding & 113.705 & -7.05 & 132 \\
\hline 201 & Dasuk & 113.86 & -6.89 & 69 \\
\hline $202 *$ & Stamet Kalianget & 113.93 & -7.05 & 3 \\
\hline 203 & Arjasa & 115.29 & -6.86 & 28 \\
\hline $204 *$ & Stamet Bawean & 112.64 & -5.84 & 30 \\
\hline
\end{tabular}




\section{Lampiran 1(b)}

Daftar Pos Hujan Jawa Tengah (termasuk wilayah administrasi Jawa Timur)

\begin{tabular}{|c|c|c|c|c|}
\hline ZOM & Pos Hujan / Stasiun Pengamatan* & Bujur & Lintang & Ketinggian $(\mathbf{m})$ \\
\hline 142 & Donorojo & 110.99 & -8.10 & 409 \\
\hline 146 & Balepanjang & 111.12 & -7.77 & 165 \\
\hline 147 & Sarangan & 111.21 & -7.68 & 1325 \\
\hline 148 & Mantingan & 111.15 & -7.38 & 113 \\
\hline
\end{tabular}

\section{Lampiran 2}

Pembagian Stasiun Referensi untuk Duga Suhu pada Zom Terdekat

\begin{tabular}{|c|l|l|}
\hline No. & \multicolumn{1}{|c|}{ Nama Stasiun Referensi (ZOM) } & \multicolumn{1}{|c|}{ ZOM Terdekat } \\
\hline 1. & Stasiun Geofisika Sawahan (159) & $\begin{array}{l}142,146,147,148,149,152,153,154, \\
155,157,158,160,156\end{array}$ \\
\hline 2. & Stasiun Klimatologi Karangploso (166) & $\begin{array}{l}161,167,168,170,169,171,165,162, \\
172,175,176,177,173\end{array}$ \\
\hline 3. & Stasiun Meteorologi Juanda (163) & $150,151,164,174,195,196$ \\
\hline 4. & Stasiun Meteorologi Banyuwangi (193) & $\begin{array}{l}178,184,181,179,188,189,187,190, \\
191,194,192,186,182,183,185,180\end{array}$ \\
\hline 5. & Stasiun Meteorologi Kalianget (202) & $201,200,199,198,197$ \\
\hline 6. & Stasiun Meteorologi Bawean (204) & 204,203 \\
\hline
\end{tabular}

